Ilustracja: Natalia Kulka

\title{
Społeczna genealogia inteligencji polskiej
}

\section{Rozdział 2. Inteligenckie getto}

\author{
Józef Chałasiński
}

Wyrażenia kluczowe: inteligencja; Józef Chałasiński

\section{Polityczne funkcje inteligencji}

Przede wszystkim należy zdać sobie sprawę z ogólnego, socjologicznego charakteru tego społeczno-dziejowego procesu, który ogarniając Polskę w okresie porozbiorowym, obok innych produktów, wytworzyt inteligencję polską jako swoistą formację społeczną.

W publicystyce zagadnienie inteligencji polskiej wiązało się zazwyczaj z tzw. sprawą polską. Z tego punktu widzenia przez inteligencję polską rozumiało się tę część elity Polski, która w okresie porozbiorowym myślała bezinteresownie o całości sprawy polskiej, sprawę tę czyniła żywotną i reprezentowała ją wobec całego kulturalnego świata. „Inteligencja, jak pisał jeden z czołowych publicystów, była strażą, która ducha narodowego nieciła $\mathrm{z}$ iskier w popiele i doniosła w rękach jego ogień do Polski państwowo 
odrodzonej"1. Ogromna rola inteligencji we wszystkich polskich ruchach wyzwoleńczych i rewolucyjnych rzuca wiele światła na tę stronę zagadnienia.

Ten punkt widzenia, który słusznie zwraca uwagę na tę ważną stronę zagadnienia inteligencji w Polsce, przesuwa całe zagadnienie ni esłuszn nie w płaszczyznę ruchów i procesów politycznej natury. Rzeczywiście dla zrozumienia genealogii inteligencji polskiej ważnym momentem jest fakt,że w okresie porozbiorowym inteligencja była jedyną spadkobierczynią szlacheckiej idei państwowej i stanowiła „moralny” rząd narodu polskiego.

Ta polityczna funkcja inteligencji polskiej w okresie porozbiorowym nie wyjaśnia nam jednak społecznej struktury inteligencji - jej społecznej genealogii, jej związków w obrębie całego społeczeństwa polskiego, jej stosunku do szlachty i arystokracji, chłopów i robotników, wsi i miast i innych elementów społecznej rzeczywistości Polski porozbiorowej.

Nie kwestionując politycznej roli inteligencji polskiej, nie można przeoczyć faktu, że w społecznej i kulturalnej strukturze Polski porozbiorowej inteligencja wyodrębniała się jako swoista warstwa społeczna. Pod wielu względami - przede wszystkim w zakresie tradycji obyczajowych i społecznych - warstwa ta była kontynuatorką stanu szlacheckiego, lecz równocześnie pod wielu innymi względami stanowisko inteligencji w społeczeństwie było zasadniczo różne niż stanowisko szlachty w dawnym społeczeństwie. Inteligencja nie zajmowała stanowiska politycznego dawnej szlachty - i pozbawiona była pańszczyźnianego folwarku jako ekonomicznej podstawy pańskiej egzystencji. Szlacheckie ambicje i szlachecki obyczaj bez pańszczyźnianego folwarku - wielkopańskość bez pokrycia.

\section{Inteligencja a folwark pańszczyźniany i rozwój kapitalizmu}

Prof. Wł[adysław] Grabski² słusznie zwracał uwagę na to, że wiele cech inteligencji polskiej wywodzi się z pańszczyźnianego folwarku-dworu.

W przedkapitalistycznej strukturze pańszczyźnianego folwarku-dworu miejsce organizowania produkcyjnej pracy zajmowało napędzanie do pracy - eksploatacja pogardzanej pracy chłopskiej, miejsce samodzielnego zawodu - łaska pańska, dająca prawo do miejsca przy stole biesiadnym i do całowania pańskiej ręki.

Do inteligencji napływał element z ziemiańskiego dworu, z pańszczyźnianego folwarku. Kształtowanie się inteligencji polskiej wiąże się nierozłącznie z jednej strony z historiq upadku folwarku i dworu, a z drugiej strony z historia rozwoju miast i przemysłu, urbanizacji i industrializacji. Inteligencja polska to produkt - niestety, jak dalej zobaczymy - produkt uboczny przeksztatcania się przedkapitalistycznej Polski szlachecko-ziemiańskiej, rolniczo-wiejskiej Polski pańszczyźnianego folwarku-dworu, w Polskę kapitalistyczna, miejska

1 Zygmunt Wasilewski: Na widowni, „Myśl Narodowa” z 15 kwietnia 1934 r., str. 233.

2 Władysław Grabski: Wpływ ustroju agrarnego folwarcznego na życie społeczne wsi. „Roczniki Socjologii Wsi” t. III/1938 r.

SLH 7/2018 | str. 2 z 21 
i przemysłową. I stąd podstawowa teza, że na kształtowanie się inteligencji polskiej, na jej genealogię społeczna spojrzeć należy z perspektywy dziejów kapitalizmu w Polsce.

Na związek kształtowania się inteligencji z rozwojem kapitalizmu zwracano już uwagę w dyskusji, jaka się toczyła przed wojną na temat inteligencji. Między innymi zwracał na to uwagę prof. Zygmunt Łempicki w studium pt.: Problemat inteligencjił. Łempicki stawiał to zagadnienie w ogólnej płaszczyźnie społeczno-kulturalnych przeobrażeń liberalno-kapitalistycznej Europy XIX w. ${ }^{4}$ Tymczasem inteligencja polska nosi piętno stosunków polskich i wiąże się z rozwojem kapitalizmu w Polsce.

Dzieje kapitalizmu nie wszędzie kształtowały się jednakowo; społeczne skutki kapitalizmu w Stanach Zjednoczonych A[meryki] P[północnej] i społeczne skutki kapitalizmu w Polsce były z gruntu odmienne. Polska w związku ze swoimi politycznymi losami nie była w pełni ogarnięta przez rozwój kapitalizmu. I właśnie inteligencja polska w swej strukturze wiąże się z cywilizacyjnym niedorozwojem Polski pod względem techniczno-gospodarczym - z faktem, że, jak ktoś się wyrazit, Polska nie miała XIX wieku.

W stosunku do szlachecko-stanowych tradycji społecznych kapitalizm był potężną miotłą, która oczyszczała teren dla mieszczaństwa. U nas takiej miotły nie było. Dla ewolucji szlachty polskiej pod wpływem kapitalizmu trzeba szukać ilustracji nie wśród Steinkellerów i Kronenbergów, lecz wśród Wokulskich. Wokulski, bohater Lalki Prusa, zbiedniały szlachetka i wzbogacony przemysłowiec, zginął marnie przez swoją romantyczną miłość do hrabianki Łęckiej. I w tym opętaniu przez urok hrabianki Wokulski wyrasta do symbolu roli szlachty w rozwoju kapitalizmu w Polsce.

Wiele rysów inteligencji polskiej to szczątkowe organy dawnej Polski szlacheckiej, to zdegenerowane szczątki szlacheckiej tradycji, których kapitalizm w Polsce nie wymiótł tak, jak gdzie indziej, gdyż był za słaby i nie ogarnął szlacheckiej masy, z której formowała się polska inteligencja. Nie jest rzeczą przypadku, że dzielnice zachodnie - Poznańskie i Pomorze - pod względem techniczno-gospodarczym najbardziej cywilizowane i miejskie, nie miały inteligencji w rozumieniu „warszawskim” lub „krakowskim”. Polityczne momenty nie wyjaśniają tu wszystkiego same przez się. Galicja, kraj najbardziej zacofany gospodarczo, miała inteligencję obciążoną najbardziej tradycjami szlachetczyzny, mimo że gimnazja galicyjskie masowo kształciły chłopów, a swobody polityczne w tym okresie były tu największe.

\section{Inteligencja polska jako uboczny produkt kapitalizmu. Rola szlachty-inteligencji w rozwoju kapitalizmu polskiego}

Postawiłem tezę, że inteligencja polska kształtowała się w ścisłym związku z rozwojem kapitalizmu w Polsce. Obecnie musimy bliżej rozpatrzyć, na czym ten związek polegał. Czy szlachta była pionierskim elementem w rozwoju polskiego kapitalizmu?

3 Z. Łempicki: Problemat inteligencji. „Marchołt”, R. I/1933, str. 208.

4 Z. Łempicki: Oblicze duchowe wieku XIX. „Kultura i Wychowanie”, R. I/1933, str. 67. 
Czy inteligencja polska kształtowała się ze szlachty w procesie cywilizacyjnej ekspansji kraju, tak charakterystycznej dla okresu rozkwitu liberalnego kapitalizmu? Nie! Kapitalizm w Polsce rozwijał się dzięki cudzoziemcom, przy bardzo słabym udziale polskiej szlachty. Inteligencja polska kształtowała się jako uboczny produkt, a nie jako pionierski element kapitalistycznego rozwoju. „Nowe formy wytwórczości krajowej zaczęły tworzyć żywioły obce, wolne od tradycyjnej bierności polskiej... A zdeklasowana inteligencja szlachecka korzystała tylko z tego, że tamci dla niej tworza gotowe posady"5.

Szlachecko-dworskie tradycje dobrego wychowania szły w parze z admiracją dla ustalonej hierarchii stanowisk społecznych, szły w parze z inklinacją do zajmowania gotowego miejsca w tej hierarchii, a nie sprzyjały pionierskim ambicjom samodzielnego torowania sobie drogi w społeczeństwie ${ }^{6}$.

Czym było wykształcenie dla inteligencji w latach międzywojennych?

Wykształcenie, stan intelektualnego posiadania, traktowane były wśród inteligencji jako tytuł do tego, aby społeczeństwo samo dało inteligentowi ekonomiczne podstawy odpowiedniej pozycji społeczno-towarzyskiej. Pod tym względem stosunek inteligenta do kraju był bardzo zbliżony do stosunku, jaki rezydenci dworscy zajmowali wobec dworu. Inteligencja traktowała siebie jako konieczny element społeczeństwa, mający prawo do ekonomicznego utrzymania przez państwo - nie poczuwając się do odpowiedzialności za gospodarcze życie kraju i do żadnej solidarności społecznej z produkcyjnymi klasami społeczeństwa - chłopami i robotnikami.Z tego stanowiska kraj, państwo, podobnie jak dawniej dwór dla szlachty, to była ,jadłodajnia dla inteligencji”, jak się wyraził jeden z publicystów.

Inteligent polski stawat się rezydentem obcego kapitalizmu w Polsce, tak jak przedtem byt rezydentem folwarku-dworu pańszczyźnianego. Kto inny za niego utylitarnie pracował i kto inny za niego utylitarnie myślał; on sam czuł się powołany tylko do duchowej, nie materialnej aktywności, tylko do pańskiej, nie do chłopskiej pracy.

Adolf Dygasiński pisze we wspomnieniach z lat szkolnych: „Zawód urzędniczy pachniał nawet osiadłemu na roli szlachcicowi, który uczuwał pod sobą grunt niepewny. Toteż trudno było docisnąć się do owych biur zapchanych przez tłumy aplikantów bezpłatnych i płatnych, dietariuszów, kancelistów.

Kobiety jednakże zwykle, jeśli nie zawsze, ułatwiały przystęp, choć nieraz wydawał się niemożliwym. Droga zaś do kobiet, to jest do ich względów, stała zawsze otworem, podobnie jak i dzisiaj przy nieco większych wymaganiach, dla każdego, kto im się podobał: miał «powierzchowność» przyjemną, dobrze tańczył i był miły «w obejściu»”

„Szlachty na Mazowszu było dużo... młodzież wymagania miała znaczne i wolała raczej biedę w miastach, niż poszukiwanie zajęć nie uchodzących za inteligentne" ${ }^{\text {. }}$.

5 Roman Dmowski: Myśli nowoczesnego Polaka. [Lwów, Towarzystwo Wydawnicze], str. 88.

6 F.Znaniecki: Ludzie teraźniejsi [a cywilizacja przyszłości. Lwów, Książnica-Atlas], str. 166 i nast.

7 Adolf Dygasiński: w Kielcach, opowiadania i uwagi o czasach szkolnych [Warszawa, Gazeta Polska], str. 81.

8 Z. Wasilewski: „Na widowni”,,Myśl Narodowa” z 15 kwietnia 1934 r., str. 233. 
Taki był trzon, masa inteligencji szlacheckiego pochodzenia, ludzi dobrej „powierzchowności”, miłych „w obejściu”, ludzi dawnego typu dworzanina, rezydenta, których staropolska literatura szlachecka określa (Górnicki w Dworzaninie) „człek biesiadny”, „czysty, gładki pachołek”, czyli człowiek obdarzony towarzyskimi zaletami i zaprawiony do udziału w „grach rozmownych”.

Typ rezydenta-dworzanina, dominujący typ dawnej rzeczywistości szlacheckiej - bo i sam właściciel dworu do tego typu należat - wraz ze szlachtą rozszerzył się na inteligenckie skupienia w miastach. Bez samodzielnego zawodu, wisząc u klamki pańskiej, szlachecki rezydent biernie przystosowywał się do konsumpcyjnej egzystencji w ramach kapitalizmu. Czuł się człowiekiem honoru i, zgodnie ze szlachecką tradycją, honor kazał mu stawać w potrzebie, gdy kraj o to wołał. Powstania i sprawa niepodległości to były dla niego sprawy jego honoru.

Ale rezydent nie myślał nigdy ekonomicznymi kategoriami. Rezydent nie brał nigdy udziału w tworzeniu gospodarczej rzeczywistości kraju i nie czuł się za nia odpowiedzialny - sprawy gospodarcze to nie były sprawy jego honoru. Rezydenta cechowała niechęć do produktywno-utylitarnych zajęć - i ten rys zachowała inteligencja polska po szlachcie.

Abstynencja od życia gospodarczego, we wszelkich jego przejawach, tak intelektualnych jak i praktyczno-zawodowych, brak poczucia rzeczywistości gospodarczej - to charakterystyczny rys inteligencji polskiej. I stąd także paradoksy naszego niedawnego życia politycznego, ideologia mocarstwowości Polski - styl wielkopański - przy zupełnym opanowaniu podstawowych dziedzin przemysłu przez kapitat zagraniczny.

Czołową postać społeczno-narodowego życia kulturalnej Polski drugiej połowy XIX w. stanowił powieściopisarz-literat, a nie inżynier-przedsiębiorca. Inżynier polski, owszem - ale na Syberii. Inteligencja polska kształtowała się ze szlachty nie w drodze ekonomiczno-cywilizacyjnej ekspansji, lecz w procesie degradacji ekonomicznej i społecznej żywiołu szlacheckiego.

\section{Inteligencja a proces spotecznej degradacji szlachty}

Przyjrzyjmy się bliżej procesowi kształtowania inteligencji. Upadek polityczny państwa z jednej strony, a podmuch kapitalizmu z drugiej - podważyły podstawowe warunki egzystencji szlachecko-ziemiańskiego dworu. Rozpoczął się szlachecki exodus do miast. Trzon inteligencji miejskiej, który zadecydował o jej społecznym i duchowym obliczu, nie powstał w drodze społecznego awansu emancypujących się mas ludowych, lecz z emigrantów dworu ziemiańskiego i pańszczyźnianego folwarku.

Degradacja społeczno-polityczna, jakiej rzesze ziemiańskie podlegały na skutek politycznej katastrofy upadku państwa i kolejnych powstań, pociągających za sobą konfiskaty majątków szlacheckich; degradacja wskutek uwłaszczenia chłopów, odbierająca ziemiaństwu władzę i znaczenie w społeczeństwie; degradacja wskutek pauperyzacji

SLH 7/2018 | str. 5 z 21 
wywołanej przez przejście gospodarki folwarcznej pańszczyźnianej na kapitalistyczną to ogromny kompleks faktów społecznych, które należy wziąć pod uwagę, rozpatrując strukturę polskiej inteligencji.

Inteligencja polska kształtowała się z polskiej szlachty w procesie jej degradacji ekonomicznej, spotecznej i politycznej.

Emigracja żywiołu ziemiańsko-szlacheckiego do miast nie była emigracją typu zdobywczego; to nie była zdobywcza ekspansja, lecz ucieczka przed bankructwem społecznym i kulturalnym.

Do miasta uciekano w samozachowawczym dążeniu do ratowania zagrożonej społeczno-duchowej pozycji. Do miasta uciekano w poszukiwaniu spokoju, w poczuciu bezsilności wobec nowych procesów społecznych, jakie wieś nurtowały po uwłaszczeniu, w poczuciu niezdolności do wzięcia udziału w tych procesach, w braku poczucia odpowiedzialności za nie. Dla wielu, jak dla Hipolita Niechcica z Nocy i dni Marii Dąbrowskiej, ucieczka do miasta to było odejście na emeryturę.

Hipolit Niechcic „pragnął głównie spokoju. Spokoju - nie w znaczeniu opanowania tych rozmaitych spraw, co szarpią życiem, ale spokoju w znaczeniu odejścia na ubocze od wszystkiego, czym człowiek powinien się troskać i za co winien żywotem swym odpowiadać. Dlatego uciekł do miasta jako do obcego środowiska, w którym o nic nie nagabywany będzie mógł żyć z cicha resztką tego, co mu zostanie"9.

$W$ ten sposób w mieście powstawaty getta szlacheckie jako zjawiska peryferyczne, marginesowe, nie mające znaczenia dla kapitalistycznej struktury miasta. Były to skupienia rozbitków i uciekinierów dworu ziemiańskiego. Zapewne, część z nich to był element szukający terenu dla swojej aktywności duchowej - ale i ci szli raczej po tradycyjnej linii amatorskich zainteresowań szlacheckich - literatury, sztuki, rzadziej nauki.

Trzeba przy tym podkreślić, że zarówno tych, co dążyli do miasta, jako do środowiska aktywności społeczno-kulturalnej, i tych, co uciekali do niego „na emeryturę” ziemiańską, cechował wspólny rys psychologiczny bardzo istotny dla zrozumienia społeczno-psychologicznej struktury inteligencji miejskiej w Polsce. Ten rys - to lęk przed schłopieniem, obawa przed deklasacją, pragnienie zabezpieczenia dzieci przed koniecznością przejścia do ordynarnych zawodów.

„Średni właściciel ziemski - mówił cytowany już Hipolit Niechcic z Nocy i dni - skazany jest na zagładę, bo jak chłop bez wymagań żyć nie będzie, a jak pan - też nie może”10. Uciekał więc ziemianin do miasta, bo tam w obcym środowisku łatwiej było żyć w ułudzie kontynuacji pańskiej egzystencji.

W kapitalistycznym mieście zdegradowany szlachcic zajmowat miejsce pariasa - ale aspiracje miał wielkopańskie.

9 Maria Dąbrowska: Noce i dnie, t. II [Warszawa, Towarzystwo Wydawnicze], str. 26-27.

10 Maria Dąbrowska: Tamże, str. 26.

SLH 7/2018 | str. 6 z 21 
Z faktem, że inteligencja polska kształtowała się ze szlachty w procesie jej degradacji, wiążą się liczne istotne rysy społecznego oblicza inteligencji. Zatrzymam się tutaj na jednym rysie charakterystycznym, zwłaszcza dla galicyjskiej inteligencji urzędniczej. Mam na myśli skłonności biurokratyczne. Na skłonności biurokratyczne zdeklasowanej szlachty słusznie zwracał uwagę St[anisław] Szczepanowski w Nędzy Galicji. Skąd te skłonności? Przede wszystkim z admiracji szlachcica dla hierarchii społecznej i związanego z nią rytuału. Po wtóre, zdeklasowanemu szlachcicowi papierowa formalistyka biurokratycznego urzędowania dawała namiastkę dawnej sfery jego społecznej ważności i wielkości. Papierowa formalistyka to rodzaj społeczno-towarzyskiego rytuału, który ma odgradzać biurokratę od plebsu, to rytuał wymagający znawstwa. Przy pomocy papierowej formalistyki „dusza” zdegradowanego arystokraty broni się przed zetknięciem z rzeczywistością. Czymże byłby galicyjski hrabia na stanowisku starosty powiatowego czy radcy namiestnictwa, gdyby urzędowanie było tak proste, że mógłby je sprawować każdy rozsądny chłop? Trzeba je było zrobić skomplikowaną arystokratyczną dziedziną. Większość tzw. intelektualnych zajęć biurowych to nie są zajęcia inteligentne w swojej istocie; inteligencja nadała im charakter zajęć wyższych pod wpływem swoich pańskich ambicji. W inklinacjach biurokratycznych tkwi samoobronna reakcja degradującej się szlachty. Ale na tę samą chorobę biurokracji cierpiał inteligent chłopskiego pochodzenia o pańskich ambicjach.

Demokratyczne pochodzenie nie jest bynajmniej gwarancją demokratycznych aspiracji. Łatwo być demokratą - mówi jeden z bohaterów inteligenckich powieści Wł[odzimierza] Perzyńskiego - gdy się należy do arystokracji, ale jak być demokratą, gdy się ma w rodzinie szewca?

Gdy dr Judym, syn szewca z ulicy Ciepłej, stanął oko w oko z pięknym, wykwintnym, pełnym smaku i elegancji nieskażonej pracą panem Karbowskim, ,z głębi duszy młodego lekarza wychylił się znowu żal gorzki i nienasycona zazdrość, czemu i on, czemu i on..."11. Czemu i on nie jest takim kwiatem tuberozy?

Inklinacje biurokratyczne zdradza zarówno zdeklasowany szlachcic, jak i inteligent chłopskiego pochodzenia, stylizujący się na pana. I dodajmy, że inklinacje te przejawiają się nie tylko w dziedzinie biurowej. Papierowa formalistyka przenika także do sfery „uczoności” i wykształcenia.

„Biurokratyczna” może być praca doktorska, podobnie jak sposób urzędowania.

Zjawiska tego nie tłumaczy powołanie się na c.-k. wpływy. Wzory szły stamtąd, z dworu Franciszka Józefa, ale przemożny urok tego dworu wśród szlachty galicyjskiej staje się zrozumiały na podłożu politycznej, ekonomicznej i społecznej degradacji szlachty galicyjskiej w kraju gospodarczego zacofania i przysłowiowej nędzy Galicji.

11 Stefan Żeromski: Ludzie bezdomni, t. I [Warszawa, Towarzystwo Wydawnicze], str. 174. 


\section{Elementy getta inteligenckiego. \\ Znaczenie kultury towarzyskiej}

Z procesem degradacji szlacheckiej wiąże się inny rys środowiska inteligenckiego znaczenie kultury towarzyskiej. Chroniczne niebezpieczeństwo unicestwienia w obcym żywiole kapitalistycznego miasta przy równoczesnym poczuciu bezsilności i niezaradności to było tło, na którym kształtowała się samoobronna aktywność szlachecko-inteligenckiego środowiska. Aktywność samoobronna, defensywna, nie pionierska, nie zdobywcza. Stać się niczym! Oto niebezpieczeństwo, jakie groziło falom uciekinierów, których przeobrażenia polityczne i społeczno-gospodarcze wyrzucały z dworów i dworków na bruk miejski.

Uciekinierzy dworu ziemiańskiego w mieście garnęli się ku sobie, trzymali się razem, tworząc odrębne skupienia ludności miejskiej - społeczno-towarzyskie getto. Więź społeczną tych skupień stanowiły przede wszystkim stosunki towarzyskie. Na podłożu stosunków w obrębie „dobrego towarzystwa” dawni rezydenci dworu ziemiańskiego mobilizowali się „duchowo” dla samoobrony. W mieście stosunki towarzyskie pozostały główną podstawą grupowej łączności inteligencji; znaleźć się poza sferą stosunków towarzyskich znaczyło odpaść od swoich, pozostać samemu, albo stoczyć się do niższych warstw społecznych. „Salonik” to był podstawowy element inteligenckiego domu w mieście, sprzed pierwszej wojny światowej.

„Naturalna potrzeba życia towarzyskiego - pisał warszawski „Głos” w 1893 r. - dochodzi u nas, zwłaszcza w Warszawie, a najbardziej w sferze osób mających pretensję do przywileju inteligencji - do jakiejś potwornej przesady"12.

W związku z olbrzymią rolą, jaką stosunki towarzyskie posiadały dla deklasującej się szlachty, pozostawało dążenie do utrzymania się na poziomie towarzyskiego życia. Stąd ta masa wysiłków oszczędnościowych i poświęcenia, jakie inteligencja wkładała w to, aby odpowiedzieć wymaganiom towarzyskiego życia w zakresie ubrania i mieszkania. Nie móc utrzymywać towarzyskich stosunków, to znaczy dać się zdeklasować. Trzeba bywać, aby nikt nie mógł podejrzewać, że się na psy schodzi. Stosunki towarzyskie pozostały bowiem zasadniczą płaszczyzną kontaktów inteligencji.

Z utratą majątku, władzy i społecznego znaczenia, jakie było przywiązane do posiadania folwarku, formy towarzyskie zyskiwały na znaczeniu. Dla szlacheckiego pariasa obycie towarzyskie było często jedynym majątkiem, jaki mu pozostał, w każdym razie bardzo ważną częścią kapitału wyższości społecznej, jakim jeszcze rozporządzał. Dobre maniery to była reszta jego wielkopańskiej egzystencji. Dziedzic na rozległych włościach mógł sobie lekceważyć formy towarzyskie, miał dość realnych podstaw swojego społecznego znaczenia, ale zubożały potomek tego dziedzica rzucony na rynek miejski lekceważyć ich nie mógł, gdyż była to resztka jego kapitału pańskości, jaka mu pozostała. Tą resztką utrzymywał się jeszcze na poziomie swojej pańskiej sfery. Im bardziej kruche stawały się

12 „Głos”. W-wa z 9/21 stycznia 1893 r., str. 31-32 „Z kraju”.

SLH 7/2018 | str. 8 z 21 
materialne podstawy bytu, im bardziej słabło moralne znaczenie warstw wyższych, tym większej roli dla nich samych, w ich własnym samopoczuciu nabierała ich osobista sztuka bycia, dobre wychowanie. Z tym wiąże się także charakterystyczny egocentryzm osobowości inteligenta, wyolbrzymiona drażliwość na punkcie własnej osoby - osobistej godności, honoru, co znakomicie zanalizował Znaniecki w „ludziach dobrze wychowanych”.

Stosunki towarzyskie mają jeszcze inne znaczenie dla getta inteligenckiego. Ludzie getta to są ludzie bezprodukcyjni i jałowi, a równocześnie posiadający poczucie wielkości; nie wytwarzają nic, co by im dawało obiektywne sprawdziany własnej wartości i wielkości. Stąd ustawiczna potrzeba dowodów uznania. Stosunki towarzyskie są im potrzebne „nie tyle dla wymiany myśli i podniety intelektualnej, ile dla wymiany wzajemnego uznania i podniety społecznej"13. Człowiek getta inteligenckiego sam potrzebuje komplementów i tak samo odczuwa potrzebę prawienia komplementów. Sam potrzebuje komplementów dlatego, że wobec własnej obiektywnej bezprodukcyjności to są jedyne dowody ważności jego osoby, która jest ogniskiem jego zainteresowań. Ale równocześnie odczuwa potrzebę prawienia komplementów, zarówno dlatego, że pragnie być w zgodzie ze zwyczajem, jak i dlatego, że ten zwyczaj prawienia komplementów pozwala mu ukryć swoją nieżyczliwość dla ludzi i brak sympatii. Bo inteligenckie getto, jak każde getto, to jest kłębowisko jadowitych żmij, w którym amatorskim kunsztem jest robienie intryg, a do najprzyjemniejszych i najpospolitszych społecznych uczuć należy cicha solidarna radość z kompromitowania się bliźnich.

Wzajemna życzliwość rodzi się sponad osobistego spojrzenia na innych i na samego siebie ze stanowiska jakiegoś wspólnego obiektywnego zadania. Tak patrzą na siebie ludzie zespołu, który pracuje nad wykonywaniem obiektywnego zadania. W środowisku zaś takim, jak getto inteligenckie, osoby, a nie obiektywne zadania stanowią ogniska zainteresowań i uczuć. Przy takiej „personalistycznej” orientacji zainteresowań i uczuć getta, przy równoczesnej bezprodukcyjności i braku wspólnych obiektywnych zadań, uczestnik getta staje się łatwo dla innych członków getta anty-osobistym rywalem wyposażonym w ładunek potencjalnej nieżyczliwości i odpowiedni ładunek komplementów. Ludzie getta nie lubią jawnego oburzenia moralnego, tym mniej otwartego potępienia, nie z obawy przed popełnieniem błędu, ale przed - skandalem. Intryga to żywioł tego środowiska. Tę psychologię getta utrzymuje w ryzach obowiązująca naczelna zasada dobrego wychowania - konformizmu, poprawności, „nie wypada”!

Z pauperyzacją i degradacją ekonomiczną potęgowało się znaczenie konformizmu, poprawności nie tylko w sferze towarzyskiej, lecz także w sferze poglądów społecznych, politycznych i religijnych. Magnat Leon hr. Rzewuski, potomek hetmańskiego rodu, dziedzic zamku w Podhorcach, mógł bezkarnie uprawiać socjalizm w finansowanym przez siebie Iwowskim „Postępie”. On to podobno pierwszy w polskiej publicystyce w swoich artykułach w „Postępie” wprowadził wyrazy burżuazja, proletariat i inne ${ }^{14}$.

13 F. Znaniecki: Ludzie teraźniejsi, str. 152.

14 E. Haecker: Historia socjalizmu w Galicji [i na Śląsku Cieszyńskim. Kraków, Towarzystwo Uniwersytetu Robotniczego], str. 54. 
Hrabia Rzewuski, który później znajduje się wśród założycieli konserwatywnego "Czasu”, mógt sobie pozwolić na takie fanaberie, nie narażając swojego stanowiska społeczno-towarzyskiego. Ale zubożały szarak szlachecko-inteligencki, bez latyfundiów uprawiając non-konformizm, narażał się na odpadnięcie od szlachty-inteligencji wraz ze swoimi dziećmi.

Dobre wychowanie to naczelna zasada inteligenckiego getta obowiązująca zarówno w życiu towarzyskim, jak i w poglądach i przekonaniach. „Ludzie dobrze wychowani wszędzie tworzą osobną, «wyższą» warstwę społeczną, wyraźnie odgraniczającą się od «niższej» reszty społeczeństwa. Odgraniczenie to polega nie na unikaniu stosunków społecznych w ogóle, lecz na zachowywaniu takiej odległości społecznej między sobą a niższymi, aby można było ignorować ich oceny, jako nie dotyczące «jaźni» człowieka dobrze wychowanego, tylko jego stanu lub funkcji społecznej... Warstwa «dobrze wychowanych» może się dzielić na różne zespoły i wspólnoty o różnych tradycjach wychowawczych, i te zespoły i wspólnoty mogą być nierówne stanowo, jak senatorowie i rycerstwo w Rzymie, duchowieństwo, szlachta i wyższe mieszczaństwo w późnym średniowieczu, lub dziś arystokracja rodowa, obywatelstwo ziemskie (ang. country gentry), dziedziczna plutokracja, dziedziczna średniozamożna burżuazja, wreszcie «inteligencja» zarobkująca. Lecz w odgraniczeniu od ludzi «źle wychowanych» są one solidarne"15.

Rytualizm towarzyski, towarzyski ceremoniał stał się istotnym środkiem utrzymania społecznego dystansu, podtrzymywania uroku społecznego ludzi, którym los odbierał inne podstawy przewagi i wyższości społecznej. We wszystkich grupach zagrożonych przez degradujące rozpuszczenie się w szerszych zbiorowiskach wzrasta znaczenie samoobronne obyczajowego rytualizmu.

Przestał istnieć pańszczyźniany folwark, jako realna podstawa wielkopańskiej egzystencji; folwark, majątek ziemski, przeważnie gdzieś daleko na Ukrainie, przeszedł do rodzinnej legendy; tym większego znaczenia nabierał ów wzór „człeka biesiadnego”, owego „pachołka gładkiego”, zaprawionego „w grach rozmownych”, jak pisano w staropolskiej literaturze.

Stanowisko towarzyskie stało się podstawowym elementem społeczno-obyczajowego wzoru inteligenta polskiego. Wszystko jedno, czy chodzi o urzędnika w banku, czy o profesora uniwersytetu - obaj należeli i należą do inteligencji polskiej nie przez walory umysłu, lecz przez stanowisko towarzyskie. Bez stanowiska towarzyskiego nie było inteligenta - ono należało do jego obyczajowej definicji.

Stanowisko towarzyskie, pojęte jako kryterium samoistne, jako niezależne stanowisko w społeczeństwie, wolne od zmazy utylitarnego wysiłku, stawiające jednostkę ponad poziom zwykłych śmiertelników - oto istotny element sztuki bycia inteligenta polskiego.

I na tym polega różnica pomiędzy pojęciem inteligenta i intelektualisty. Inteligencja to osobna warstwa społeczno-towarzyska.

Jak wygląda wzorowy inteligent polski? Otwieramy powieść I[gnacego] Dąbrowskiego pt. Matki i czytamy opis spotkania ze znajomym gdzieś w miejscu publicznym.

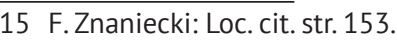

SLH 7/2018 | str. 10 z 21 
„Moje uszanowanie pani!

Pani Julia spojrzała nieco zdziwiona...

Ale już pierwszy rzut oka był dostatecznym, ażeby stwierdzić przynależność owego obcego do tej warstwy towarzyskiej, w której ludzie nawet sobie nieznajomi nie czują się sobie obcy.

Siedział przed nią mężczyzna jeszcze dość młody, nie tyle przystojny, ile o interesującej mocno twarzy typowego inteligenta, ubrany w letni popielaty garnitur świeżości i kroju bez zarzutu, a nie wystrojony" ${ }^{16}$.

Tak wygląda typowy inteligent. W jego wyglądzie zamknięty jest cały urok człowieka nie potrzebującego zarobkować. Dla ludzi o arystokratycznych tradycjach wolności od pracy, których warunki życia do pracy zmusiły, jakże cennym jest zachowanie sztuki bycia człowieka nie potrzebującego zarobkowo pracować. Wyglądać tak, jakby się zarobkowo pracować nie musiało. Taki jest wzór inteligenta kultywowany w życiu towarzyskim inteligencji. Ten wzór każe Jadwidze Solnickiej z powieści Nie było nas, byt las Perzyńskiego, biednej urzędniczce z sądu, robić z koszyka elegancki pakunek, gdy idzie po zakupy. Ten wzór sprawiał, że urzędnik wojewódzki pan Zaniemski w Niedobrej miłości Nałkowskiej z plugawego, niewiarogodnie brudnego mieszkania „wychodził co rano do pracy czysty, wyświeżony, pachnący i nawet - można powiedzieć wielkopański... brał zawsze udział w najświetniejszych... uroczystościach i nawet mógł być uważany za ich ozdobę"17.

„Była... metoda.. Z jaką znosił swoje ubóstwo... po młodości spędzonej w dostatkach zachowywał się wobec swych dzisiejszych warunków tak, jakby nic szczególnego się nie stało, jakby nie warto było o tym wspominać... Nędza jego domu nie mogła jakby wcale dosięgną́ jego osoby"18.

Wielkopańska sztuka bycia to ostatnia przegroda społeczna, która odgradzała szlachtę-inteligencję od pospólstwa. Być panem „z ducha” na dyskretnie ukrywanym „śmietniku” dawnej rodowej świetności.

Inteligent to człowiek, z którym można było utrzymywać stosunki towarzyskie, któremu podawało się rękę, zapraszało do stołu. Inteligent to stanowisko społeczno-towarzyskie, wykluczające ordynarne formy zarobkowania - inteligent nie zarabiał, on otrzymywał gażę, uposażenie, honorarium. Niedawno jeszcze lekarzowi wręczało się honorarium dyskretnie w kopercie.

Salonik inteligencki kontynuował styl kulturalny przedkapitalistycznego dworu ziemiańskiego. Cechą tego stylu było powiązanie kultury intelektualnej ze społeczno-obyczajowym wzorem człowieka nie potrzebującego zarobkować.

16 J. Dąbrowski: Matki, powieść współczesna. W-wa [Biblioteka Polska], str. 353.

17 Zofia Nałkowska: Niedobra miłość [Romans prowincjonalny. Warszawa, Gebethner i Wolff], str. 79.

18 Zofia Nałkowska: Loc. cit. str. 78. 


\section{Stosunek inteligencji do arystokracji}

Podkreśliłem na wstępie, że socjologiczną strukturę inteligencji rozumie się należycie dopiero wtedy, gdy się weźmie pod uwagę społeczny proces tworzenia się inteligencji. Strukturę inteligencji polskiej w sposób istotny określił fakt,że powstała ona z elementu szlachecko-ziemiańskiego w drodze społecznej degradacji, a nie społecznego awansu.

Kształtowanie się inteligencji w procesie społecznej degradacji dworów zaciążyło w sposób decydujący na postawie inteligencji względem arystokracji. Dla uciekinierów [z] dworu ziemiańskiego migracja do miast to była konsekwencja nieszczęścia. Ich ideał życia stanowiła nadal arystokracja ziemiańska rodowo-majątkowa. Nieszczęście, ruina majątku oddalały ich od tego ideału, który jednak nie przestał być w dalszym ciągu dla nich najwyższym kryterium wartości społecznej człowieka. Stąd swoiste onieśmielenie pariasa inteligencji wobec utraconego ideału, od którego odsunąt ją los. Stąd poczucie niższej wartości wobec arystokracji.

Bliższe lub dalsze stosunki towarzyskie z arystokracją stały się ważną podstawą wzajemnej oceny towarzysko-społecznej wśród inteligencji. Arystokratyczni krewni i znajomi podnosili towarzyski splendor rodziny. Oceniano się wzajemnie nie według tego, jak kto daleko doszedł w swoich pozytywnych ambicjach życiowych, lecz według tego, kto był bliżej lub dalej od arystokracji. Ci, co byli bliżej niej, czuli się wyżej od tych, którzy znajdowali się dalej. Dlatego, jak już podkreślałem, tak wielkie znaczenie miało utrzymanie rodziny na poziomie towarzyskim.

Na tle poczucia niższości inteligencji względem arystokracji specjalnego znaczenia nabierała kultura umysłowa inteligencji. Elementy tej kultury wyniosła inteligencja z magnackiego dworu, ale w strukturze socjologicznej inteligencji nabrały one odrębnego znaczenia, gdyż oddzieliły się od majątku i władzy.

Dla magnata sprawy kultury to była sfera rozrywki, kaprysu, tak jak polowanie i sport. Mógł sobie pozwolić na nie, bo stać go było na to. Mógł z nich również zrezygnować. Nawet mecenat kulturalny nie należał, przynajmniej w Polsce, do zwyczajowych obowiązków społecznych magnatów, nie mówiąc o twórczości. Dziedziczne włości dawały magnatowi dość władzy i znaczenia w społeczeństwie i bez tego. A już zawodowe zajmowanie się sprawami kultury nie licowało zgoła ze stanowiskiem szlachcica-ziemianina.

„Gdy Fryderyk hr. Skarbek obejmował katedrę ekonomii na Uniwersytecie Warszawskim (1818 r.) nie chciano uszom wierzyć, że hrabia, człowiek zamożny, chciał zostać... bakałarzem. Teść jego Gzowski, zamożny ziemianin z Kujaw, podobno namawiał córkę, by z tego powodu rozwiodła się z mężem"19${ }^{19}$.

Inaczej rzecz się miała ze spauperyzowaną częścią szlachty. Wyniesionej ze dworu kultury nie mogła ona lekceważyć, gdyż to była główna podstawa jej społecznego

19 Kurier Warszawski: Książka jubileuszowa 1821-1896, str. 9.

SLH 7/2018 | str. 12 z 21 
znaczenia wobec arystokracji. Stosunek więc jej do kultury musiał być poważny, był to bowiem jej duchowy majątek. Powaga zainteresowań kulturalnych to wytwór nie dworu wielkopańskiego, ale zubożałej szlachty i inteligencji.

Magnat, książę Czartoryski mógł się zabawiać pisaniem sztuk scenicznych, ale zajęcie to nie miało istotnego znaczenia dla jego stanowiska społecznego. Ale czymże byłby Stefan Żeromski, gdyby nie był wspaniałym artystą pióra? Zubożały szlachcic, poprzez głodowe lata inteligenckiej egzystencji warszawskiej, stał się czołowym pisarzem całego pokolenia inteligencji polskiej. I jako mistrz pióra stanął w rzędzie nowego, duchowego typu arystokracji - jako arystokrata duchowy, w poczuciu reprezentowanych przez siebie wartości mógł się przeciwstawiać dawnej arystokracji rodowej. Ale czy się całkowicie uwolnił od jej społeczno-towarzyskiego uroku? Ile razy dr Judym padał ofiarą tego czaru, jaki szedł na inteligencję polską z rożnych polskich Nawłoci?

Arystokracja, szlachta-ziemiaństwo, najwyższe sfery towarzyskie stanowiły przecież autorytet kulturalnego smaku. Uznanie ze strony tego środowiska nie mogło być obojętne dla inteligencji - ludzi talentów i pióra. Talent i pióro muszą mieć swoich znawców i odbiorców i ci odbiorcy urabiają ich sobie. Wspomnienia Wojciecha Kossaka lub Pamiętniki Fałata doskonale ilustrują, jak wysoko cenią sobie artyści i malarze uznanie głów koronowanych i w ogóle osób wysoko postawionych w hierarchii społecznej i towarzyskiej. Nie trzeba się również rozwodzić nad tym, jak wielką rolę wśród tych odbiorców produktów ducha ludzkiego odgrywała kobieta-bóstwo, wytwór najwyższych sfer towarzyskich. Dostatecznie świadczy o tym twórczość Stefana Żeromskiego, w której kobieta z tych sfer odgrywa tak przemożną rolę w dynamice życiowej jego bohaterów. Jako mecenas i główny odbiorca sztuki i literatury szlachta-ziemiaństwo należała do jednego środowiska kulturalnego ze szlachtą-inteligencją.

W krajach nowoczesnego kapitalizmu kultura intelektualna została zasymilowana przez mieszczaństwo. Tam inteligencja miejska pochodzenia szlachecko-ziemiańskiego mogła ratować swoją pozycję socjalną przez duchowe zespolenie się z aspiracjami nowej warstwy, a nawet $z$ aspiracjami emancypującej się klasy robotniczej.

W Polsce w rezultacie cywilizacyjnego zacofania kraju wysoka kultura intelektualna służyła inteligencji nie do wysunięcia się na czoło nowych warstw społecznych w charakterze ich elity intelektualnej, lecz głównie do utrzymania łączności z arystokracją rodowo-majątkowa. Inteligencja polska, zamknięta w swoim getto społeczno-kulturalnym, pielęgnowała swoją kulturę nie jako awangarda i elita warstw niższych, lecz jako satelita arystokracji rodowo-majątkowej i szlachty ziemiańskiej.

Oczywiście, sytuacja psychologiczno-socjologiczna poszczególnych indywidualności pisarskich była zróżnicowana. Sienkiewicz i Świętochowski, Prus i Weyssenhoff, Żeromski i Reymont, Orzeszkowa i Rodziewiczówna stanowią nie tylko kontrastowe ilustracje twórczych indywidualności, lecz także odmiennych powiązań socjologicznych. W każdym konkretnym wypadku bardzo trudno wydzielić elementy sytuacji i tendencji typowych od

SLH 7/2018 | str. 13 z 21 
procesów i tendencji indywidualizujących. Oto Aleksander Świętochowski, indywidualista i intelektualista, „apostoł prawdy” wolteriańskiego typu, wróg społeczeństwa szlacheckiego, wróg wszelkiego stada ludzkiego - czy może być traktowany jako satelita arystokracji rodowo-majątkowej? Ale czy tego arystokratę intelektualizmu można posądzać o ambicję sprawowania duchowego kierownictwa nad masami ludowymi i wyrażania ich potrzeb? Rozbijał tradycyjną arystokrację i występował w obronie praw człowieka bez sympatii dla masowych ruchów społecznych.

Zwracając uwagę na te trudności wszelkiej typologii socjologicznej nie waham się twierdzić, że kultura inteligenckiego getta nie rozwijała się na podłożu aspiracji objęcia duchowego kierownictwa nad masami ludowymi, lecz na podłożu dorównania, a nawet zdobycia intelektualnej przewagi nad arystokracją rodowa. Inteligencja, nie mogąca rywalizować $z$ arystokracja rodowo-majątkowa $w$ innej płaszczyźnie, tym więcej ambicji wkładała w przewyższenie arystokracji w zakresie intelektualnej „duchowej” kultury.

Wojciech hr. Dzieduszycki w Listach ze wsi ${ }^{20}$ pisał o stosunkach galicyjskich z lat dziewięćdziesiątych, że „całe wewnętrzne polityczne życie kraju naszego streszcza się w tym, że rozmaite arystokracje toczą walkę o panowanie nad krajem..." Uwaga ta jest równie trafna w odniesieniu do procesów społeczno-kulturalnych.

Kultura polska ostatniego wieku rozwijała się $\mathrm{w}$ procesie rywalizacji inteligencji i arystokracji rodowo-majątkowej, nie zaś w procesie dostosowywania się inteligencji do roli intelektualnego wykładnika potrzeb i aspiracji mas ludowych.

W walce o stanowisko arystokracji umysłowej w społeczeństwie polskim inteligencja miejska osiągnęła przewagę nad arystokracją rodowo-majątkową. Inteligencja miejska, a nie arystokracja rodowa wytworzyła ośrodki myśli naukowej i twórczości literackiej.

Niemniej w polskiej rzeczywistości społeczno-kulturalnej kultura intelektualna aż po nasze czasy występuje jako element towarzyskiego stanowiska w obrębie osobnej arystokratycznej warstwy inteligencji.

Inteligent jako typ społeczny łączy: 1) stanowisko społeczno-towarzyskie członka wyższej warstwy spoteczno-kulturalnej, 2) z kultura intelektualna, ale z kultura intelektualna amatorską, a nie zawodową, z kulturą intelektualną, której styl nadaja wartości intelektualne niepotrzebne utylitarnie, pańskie, charakterystyczne dla dawnej kultury arystokratyczno-dworskiej.

Emancypacja intelektualna inteligencji od arystokracji rodowo-majątkowej nie poszła tak daleko, aby zerwać całkowicie łączność między nimi. Inteligencja nie wyzwoliła się spod duchowego i społecznego protektoratu arystokracji.Ze wszystkich sfer społecznych arystokracja rodowo-majątkowa utrzymała najściślejsze kontakty z inteligencją i jej ośrodkami kultury umysłowej. W tym kierunku działały zarówno i tendencje getta inteligenckiego, zabiegającego o to, by zachować łączność z arystokracją, jak i tendencje

20 Wojciech Dzieduszycki: Listy ze wsi 1889-1890, t. I [Lwów, Gazeta Narodowa], str. 86.

SLH 7/2018 | str. 14 z 21 
arystokracji, aby nie dopuścić do całkowitego wyemancypowania się inteligencji miejskiej, zachowując nad nią protektorat. Inteligenckie getto to była właśnie sfera duchowego protektoratu arystokracji nad inteligencją.

„Ja i arystokracja” - to był problem społeczno-osobisty każdego zdegradowanego szlachcica-inteligenta; ja i arystokracja - to był problem Wokulskiego, Judyma, Podfilipskiego - całego getta inteligenckiego. Ja i arystokracja - to była oś struktury społecznego typu inteligenta.

Życie kulturalne Polski dostarcza wielu przykładów, że inteligencja polska nie czuła się wykładnikiem mas ludowych, ale zubożałym satelitą arystokracji, wobec której czuła swą niższość i onieśmielenie.

Najjaskrawiej, rzecz jasna, zjawisko to występuje tam, gdzie proces społecznej emancypacji inteligencji był najmniej zaawansowany wskutek ogólnego zacofania w rozwoju społecznym i gospodarczym. Mam na myśli Galicję, gdzie poziom „zawodowej” godności inteligencji w kontaktach z arystokracją był dużo niższy niż w Królestwie. Trzeba przy tym dodać, że galicyjska inteligencja chłopskiego pochodzenia nie wyróżniała się pod tym względem korzystnie.

Nie potrzebuję rozwodzić się nad tym, jak ściśle inteligencja polska w całej swojej kulturze i obyczaju była związana z arystokracją. Magnacko-arystokratyczny - nie mieszczański ani chłopski - jest styl inteligenckiej kultury - styl kulturowo-obyczajowych wzorów, obowiązujących po dziś dzień wśród inteligencji.

„Pochodzeniem przeważnie magnacko-szlacheckim - pisze na ten temat prof. St[anisław] Estreicher - tłumaczą się liczne charakterystyczne cechy kultury polskiej wziętej jako całość: jej wykwint zewnętrzny i błyskotliwość, pociąg do okazałości, nawet zbytku, przepychu, skłonności do wytwornej galanterii wobec kobiety. Czy weźmiemy strój polski, czy życie towarzyskie i rodzinne, czy sposób ucztowania, czy jakikolwiek inny szczegót, wszędzie te "pańskie» cechy występują i odróżniają nasz obyczaj od obyczajowości, która gdzie indziej tworzyła się pod silnym wpływem miast i mieszczan. Do dziś dnia obyczaj polski odbija tymi cechami od mieszczańskich cech obyczajów Czech albo Niemiec"21. Ten arystokratyczny styl u pariasa kapitalizmu w Polsce - jakim byt inteligent - dawał efekt komiczny.

„Obserwowałem nieraz Polaków - mówi cudzoziemiec, jeden z bohaterów powieści Choynowskiego o inteligencji polskiej - otóż jesteście dość zabawni. Macie wersalskie wychowanie francuskie, małpowane z magnackich dworów, a żadnej możności podtrzymania tych pretensji. Jeżeli wezmę do ręki bilet Anglika z czterowierszem tytułów i inicjałów - mówi mi to naprawdę o jego stanowisku społecznym, jeśli zaś czytam za granicą w katalogowym spisie «Monsieur de Zapominalski» - wiem, że to zwykły błazen. Jesteście sztywni, wszyscy macie manię wielkości i pogardę dla ludzi wychowanych inaczej.W Europie nie bardzo was lubią. Brak wam «humanitatis», poczucia wszechludzkiego

21 St. Estreicher: Problem dziejów kultury polskiej, „Przegląd Współczesny” R. X/1931 nr. 105, str. 19.

SLH 7/2018 | str. 15 z 21 
braterstwa. Tego najprostszego afektu prostej życzliwości dla ludzi. Toć we Włoszech cały wagon rozmawia ze sobą w minutę po wyruszeniu ze stacji. U was bez przedstawienia nikt ust do nikogo nie otworzy. A już wasze kobiety. Każda szwaczka pozuje na księżniczkę, każda brzydula ma pretensję do hołdów, każda idiotka pogardza całym światem. Daruj pan, ale jesteście trochę śmieszni”22.

I jeszcze jedno. Duchowa solidarność polskiej inteligencji z arystokracją miała inne jeszcze podłoże. Inteligencja i arystokracja stanowiły jeden wspólny obóz polskich Europejczyków: inteligencja i arystokracja to była polska Europa. Nie od dzisiaj i nie tylko w sferze „Wiadomości Literackich“, lecz także w sferze „Przeglądu Współczesnego“ inteligencja polska to był rodzaj arystokratycznej ambasady zachodnioeuropejskiej kultury na dzikich polach chłopskiej, murzyńskiej Polski, „przedmurza chrześcijaństwa”.

Do społeczno-kulturalnej istoty wyższych sfer polskiej inteligencji należało zawsze, że byli to „zagranicznicy” - paryżanie, rzymianie, londyńczycy, heidelberczycy, wiedeńczycy. Nieśmiertelnym wzorem tego typu polskiego Europejczyka, ambasadora Europy w kraju polskich Murzynów, był Zygmunt hr. Podfilipski Weyssenhoffa. Pan Zygmunt hr. Podfilipski nie potrafił patrzeć na Polskę inaczej, jak tylko z góry - oczami patrioty Paryża i Londynu.

Inteligencja polska - polscy Europejczycy - polscy paryżanie i londyńczycy w kraju tubylczych chłopów.

Pisarz duński Jerzy Brandes w swych wrażeniach z Polski z lat dziewięćdziesiątych, zwracając uwagę na powszechność francuskiego języka wśród arystokracji i wyższych sfer inteligencji, pisał, że „pod wielu względami Warszawa czyni wrażenie miasta prawie francuskiego"23.

\section{Inteligencja a masy ludowe}

Ze ścisłego związku inteligencji z arystokratycznymi wzorami kultury wynikają charakterystyczne tendencje kultury inteligenckiej wobec mas ludowych. Parias ekonomiczny o wielkopańskich aspiracjach pragnąt monopolu na kulturę intelektualna.

Deklasujący się element ziemiański niósł ze sobą do miasta zainteresowania intelektualne jako element życia towarzyskiego. Do saloniku miejskiego, miniatury salonu, przesiąkał salonowy typ umysłowej kultury. Z towarzyskim salonem wiąże się inteligencki ideał ogólnego wykształcenia, w którym element humanistyczno-literacki dominuje nad naukowo-przyrodniczym, element dekoracyjny nad utylitarnym, dyletancko-amatorski nad fachowo-zawodowym.

Nie dziwi nas, że w saloniku Jadwigi Solnickiej, biednej urzędniczki sądu z inteligenckiej powieści Wt[odzimierza] Perzyńskiego pt. Nie było nas, był las, „dyskutowano gorąco

22 Piotr Choynowski: Młodość, miłość, awantura [Warszawa, Gebethner i Wolff], str. 47-48.

23 J. Brandes: Polska, Lwów 1902, str. 37.

SLH 7/2018 | str. 16 z 21 
o literaturze, sztuce, polityce i upośledzeniu inteligencji”. Dyskusje o literaturze należały w dalszym ciągu do arsenału towarzyskiej sztuki bycia, tak samo jak estetyczny wzór człowieka nie potrzebującego zarobkować, zabraniający pannie Solnickiej pokazywania się na mieście z koszykiem w ręku. Wykształcenie stało się dla inteligencji elementem jej pańskiej sztuki bycia, jej dobrego wychowania.

Co więcej, w sytuacji społecznego upośledzenia kultura umysłowa nabierała tym większego znaczenia dla poczucia jej społecznej wyższości, im bardziej zacierały się zewnętrzne różnice ubiorów między inteligencją a wzbogaconym drobnomieszczaństwem.

W związku z tym pozostawała tendencja inteligenckiego getta do zmonopolizowania kultury umysłowej, wykształcenia i nauki, do izolowania jej we własnym środowisku, ponieważ zachowanie ekskluzywnego, arystokratycznego charakteru kultury umysłowej - to był warunek utrzymania społecznej przewagi inteligencji w społeczeństwie.

Gdy kultura umystowa staje się sprawa dobrego wychowania, to rozwijanie tej kultury wśród ludzi „źle wychowanych” jest ze stanowiska ludzi dobrze wychowanych oczywistym nonsensem.

A ponadto, popularyzować naukę i wykształcenie w szerokich masach to znaczyło podważać istotne podstawy znaczenia inteligencji w społeczeństwie jako osobnej, wyższej warstwy społecznej. Tendencje popularyzacji są obce kulturze inteligenckiego getta. Inteligencję cechowała tendencja do zachowania elitarnego charakteru kultury umysłowej. Inteligencji odpowiadała kultura niedostępna, kultura smakoszowska, przeznaczona tylko dla wtajemniczonych. Popularyzator nauki, sprzymierzeniec aspiracji ludowych to był wróg getta inteligenckiego, którego wyższość społeczna opierała się na izolacji i ekskluzywizmie. A przede wszystkim to był człowiek śmieszny i - źle wychowany.

Inteligenckie getto nie sprzyjało rozwojowi talentów popularyzatorskich, gdyż jego kulturalne zainteresowania wiązały się z tendencją do izolowania kultury od szerokich mas, do jej utrudniania raczej niż spopularyzowania i udostępnienia. Ta kulturalna psychologia getta inteligenckiego zaciążyła na naszych zaniedbaniach na polu popularnej książki, popularnego teatru, w czym się tak jaskrawo niezaszczytnie wyróżniamy pośród krajów Europy zachodniej.

„Młodzież inteligentna - pisał Popławski w „Głosie” w 1888 r. - winna zdemokratyzować się sama, zdemokratyzować obyczajowo, inaczej bowiem nie potrafi przystosować się do warunków swego istnienia, winna pozbyć się tych potrzeb osobistych, które czynią ją zależną od warstw uprzywilejowanych, zniewalają do zapierania się zasad swych i uczuć, do upadlających kompromisów sumienia z wymaganiami otaczającej sfery. Nie chodzi tu jedynie o ograniczenie potrzeb materialnych, które i tak inteligentny proletariusz zaspokaja licho, ale właśnie o demokratyzację obyczajową w zakresie upodobań, 
zwyczajów towarzyskich, nawet może wymagań intelektualnych, słowem stosunków osobistych"24.

„Ci... co stanowią inteligencję miasteczek - pisał Prus w „Kurierze Warszawskim” w 1885 r. - a więc: doktor, rejent, aptekarz itp., ci żyją tylko ze sobą, podniecają swoje umysły wiadomościami bieżącymi z gazet, a do gminu nie zbliżają się. Ich więcej interesują... Afgańczycy, Tonkińczycy, aniżeli szewcy, krawcy, mularze i bednarze, którzy chodzą po tych samych ulicach... Taki jest skutek naszych arystokratycznych tradycji"25.

„Jest prawdą niezbitą, a nad wszelki wyraz smutną - pisał tenże Prus w „Tygodniku Ilustrowanym" w 1886 r. - że inteligencja nie ma żadnej spójni z chłopem, nie zna go, nie rozumie, nie widzi i nie wpływa na niego. Żydowski szynkarz i lichwiarz, pokątny doradca, nawet złodziej, zesłany na pobyt w jakiejś okolicy, posiada u chłopów więcej zaufania i powagi, aniżeli inteligencja, mianująca się kierownikiem społeczeństwa. - Nie ma większej boleści, większego wstydu, jak stać się obcym wśród swoich i dla swoich. Jest to zaś punkt, do któregośmy już doszli”26.

„Istna przepaść społeczna - pisał w tym samym czasie Wojciech hr. Dzieduszycki, prof. Uniwersytetu Lwowskiego - oddziela wyższe warstwy społeczeństwa od najliczniejszych niższych: od chłopa, małomieszczanina i gminu żydowskiego. Myśmy już tak przywykli do niezmiernej orientalnej uniżoności naszego ludu, że nas już nie dziwi to, że chłop przed panem nie śmie usiąść, choć u niego nie służy, że z głową odkrytą będzie przed nim stał w największy upał lub na słocie, że go w nogi ucałuje, że przed nim uklęknie. Arystokracja kraju naszego, tj. przede wszystkim szlachta, duchowieństwo i inteligencja wyższa i ci, którzy by chcieli należeć do jednej z tych grup arystokratycznych, dbają wielce o to, aby się różnili obyczajem, strojem, a nawet mową od masy narodu, od tego, co zowiemy ludem..."27.

Tej izolacji inteligencji od mas ludowych nie przełamywało nawet masowe uczęszczanie chłopskiej młodzieży do gimnazjów, jak to miało miejsce w Galicji.

Znakomity historyk, chłopski syn, wspominając swoje lata w gimnazjum galicyjskim (w okresie 1885-1889), pisze: „dopiero w 8-ej klasie byłem kilka razy w mieszkaniu rodziny inteligentnej $u$ jednego $z$ kolegów... Bliższe jednak stosunki mogłem nawiązać tylko z kolegami pochodzenia chłopskiego"28.

Młodzież chłopska kształcąca się w gimnazjach, wychowywała się przeważnie w „norach", jakie opisuje J[ulian] Fałat w swoich Pamiętnikach ${ }^{29}$, na marginesie kulturalnego społeczeństwa; niewiele mogła się przyczynić do zmiany społecznego oblicza inteligencji

\footnotetext{
24 J. L. Popławski: Proletariat inteligentny. „Głos”, W-wa 8/20 października 1888 r. str. 493-494.

25 B. Prus: „Kurier Warszawski”, 1885 r. wedk. Z. Szweykowskiego, „Lalka” Bolesława Prusa [Warszawa, Gebethner i Wolff 1935], str. 154, odnośnik.

26 B. Prus: „Tygodnik Ilustrowany”, 1886 nr. 157, wedk. Z. Szweykowskiego, Loc. cit., str. 175.

27 W. Dzieduszycki: Listy ze wsi, t. I, str. 88.

28 F[ranciszek] B[ujak]: Drogi mojego rozwoju umysłowego, „Nauka Polska”, t. VI/1927, str. 85 i nast.

29 J. Fałat: Pamiętnik, W-wa 1935, str. 38-39.
} 
polskiej. W poczuciu poniżenia, onieśmielenia, przystosowywała się ta młodzież do obowiązujących wzorów inteligencji - szlachty. Niewielu wzbogacało kulturę polską swoimi talentami - jak J. Fałat, większość zadowalała się „pomyjami dobrobytu”, jak pisał St[anisław] Witkiewicz.

Inteligenckie getto kultury polskiej wchłaniało w siebie chłopskich przybyszów za cenę zerwania łączności z macierzystą warstwą. Silne indywidualności wyłamywały się spod tego prawa getta. Jakże jednak inaczej, jak tylko tym prawem getta, ciążącym jak przekleństwo na dziejach kultury polskiej, wytłumaczyć można fakt, że prof. B[ogdan] Suchodolski po skrupulatnym rozpatrzeniu kulturalnych stosunków Polski współczesnej w 20 roku niepodległości państwa polskiego w 1937 r., pisał: „nienaruszony pozostał ten arystokratyczny styl polityki kulturalnej... Jest tak oczywiście dlatego, iż żyjemy pod urokiem szlacheckiego mitu, iż kultura jest dobrem elity"30.

„Cały ten arystokratyzm kultury - pisze prof. B. Suchodolski - lekceważenie wielkiego dzieła upowszechniania kultury jest tym niebezpieczniejszy, iż towarzyszy mu zjawisko stabilizacji społecznej struktury Polski na poziomie wybitnie stanowym i to według stanowości najgorszego gatunku, bo sztucznej i przypadkowej... W tych warunkach jednostronna troska o kulturalną wytwórczość elity staje się bardzo łatwo popieraniem procesów i dzieł, nie odpowiadających przygłuszonym i skrępowanym możliwościom całego narodu. Popieraniem tego, co w niesprawiedliwych warunkach społecznych doszło przypadkowo do głosu, ale nie jest wcale szczytową i reprezentatywną wartością ducha polskiego"31.

W świetle takich tendencji polskiego życia kulturalnego jest rzeczą niepokojącą, że po stratach, jakie dotknęły inteligencję polską w czasie wojny i okupacji, w poważnej publicystyce nie szuka się sposobów zorganizowania wielkiej, systematycznej i przemyślanej akcji wydobywania talentów z szerokich mas społeczeństwa. Przeciwnie, w zgodzie z tradycyjną naszą obojętnością dla tego problemu, na czoło inteligenckiej publicystyki wysuwa się stary, naprawdę zużyty motyw: ostrożnie, aby nie za dużo chłopskiej młodzieży na uniwersytetach! „Nie wolno... kosztem wartości inteligencji powiększać jej ilości” - ostrzega „Tygodnik Powszechny” ${ }^{2}$. „Dziwne się wydają - kontynuuje „Tygodnik Powszechny" - niektóre wypowiedzi prasowe biadolące nad nieproporcjonalnym stosunkiem poszczególnych warstw społecznych na wyższych uczelniach"33. Dziwne?! Ta ślepota inteligenckiego getta budzi doprawdy niepokój.

Brak zainteresowania dla talentów, tkwiących w masach ludowych i marnujących się dla narodu, zgadza się z psychologią getta, z psychologią środowiska ludzi zdegradowanych i chorych na punkcie swojej wielkości. Inteligenckie getto żywi przekonanie, że poza sferą należącą do inteligenckiego getta nie ma rzeczy zasługujących na uwagę, co

\footnotetext{
30 B. Suchodolski: Polityka kulturalno-oświatowa w Polsce współczesnej, W-wa 1937 r. str. 30-32.

31 B. Suchodolski: Loc. cit.

32 W. Kętrzyński: o inteligencji polskiej, ,Tygodnik Powszechny” z 1 lipca 1945 r.

33 W. Kętrzyński: Tamże.
}

SLH 7/2018 | str. 19 z 21 
najwyżej w charakterze zabawnej murzyńskiej egzotyki - jak np. „chłopskie wesele”! (Mam na myśli, rzecz jasna, zainteresowania inteligenckiego getta, a nie społeczników czy inteligenckich prometeistów).

Brak zainteresowania dla niewyzyskanych talentów, tkwiących w masach ludowych, ma bardziej ogólne podłoże w psychologii getta. Getto nie lubi wybitnych indywidualności, getto jest w swojej istocie nieżyczliwe dla wybijających się młodych talentów i wielkości. Getto jest solidarne nie w życzliwym popieraniu talentów i uzdolnień; ono jest solidarne $w$ przeciwdziałaniu wybijaniu się nowych talentów literackich czy naukowych. Jest to solidarność ludzi jałowych i małych, którzy sami czują się wielcy i nie znoszą prawdziwych wielkości obok siebie. Tylko towarzyska taktyka umiaru i skromności obowiązująca w sferach dobrego wychowania nie pozwala ludziom z getta inteligenckiego na jaskrawe afiszowanie swojej wielkości. Nie wypada okazywać swojej wielkości. Ale poza tą taktyką kryje się brutalność uczuć wobec każdego, z kim się nie potrzeba liczyć. Ta psychologia getta tłumaczy nam bardzo wiele z powodów emigracji talentów i naukowców takich, jak Curie-Skłodowska, Bronisław Malinowski, czy Helena Modrzejewska. Inteligenckie getto, a w tym i getto uniwersyteckie, nie jest terenem dla zdobywania sławy, lecz dobrej reputacji. Ludzi sławnych getto chętnie zaprasza do siebie wtedy, gdy już sławę zdobyli za granicą. Takie sławy getto skwapliwie nostryfikuje, uznaje za swoje wielkości. Getto lubi dekorację wielkości nieszkodliwą dla siebie. Toteż uznaje, ceni i nostryfikuje dla siebie skarby kultury polskiej w osobach ludzi wielkich, którzy się już przenieśli do wieczności: kult wielkości zmarłych - o zmarłych źle mówić nie wypada - to już nie tylko taktyka uprzejmości getta, to także wyraz potrzeby uświęcania i podnoszenia własnej wielkości przy pomocy swoich „świętych”.

Z: Józef Chałasiński, Społeczna genealogia inteligencji polskiej, rozdz. 2: Inteligenckie getto (Chałasiński, 1946, ss. 27-56).

\section{Bibliografia}

Chałasiński, J. (1946). Społeczna genealogia inteligencji polskiej. Warszawa: Czytelnik. 
Article No. 1902

DOI: 10.11649/slh.1902

Citation: Chałasiński, J. (2018). Społeczna genealogia inteligencji polskiej: Rozdz. 2. Inteligenckie getto. Studia Litteraria et Historica, 2018(7). (1. wyd. 1946). https://doi.org/10.11649/sh.1902

This is an Open Access article distributed under the terms of the Creative Commons Attribution 3.0 PL License, which permits redistribution, commercial and non-commercial, provided that the article is properly cited. www.creativecommons.org/licenses/by/3.0/pl

(ㄷ) Katarzyna Chałasińska-Macukow \& Grzegorz Chałasiński 2018

Publisher: Institute of Slavic Studies, Polish Academy of Sciences, Warsaw. 